\title{
Salinisphaera hydrothermalis sp. nov., a mesophilic, halotolerant, facultatively autotrophic, thiosulfate- oxidizing gammaproteobacterium from deep-sea hydrothermal vents, and emended description of the genus Salinisphaera
}

\author{
Correspondence \\ Costantino Vetriani \\ vetriani@marine.rutgers.edu
}

\author{
Melitza Crespo-Medina, ${ }^{1,2}$ Aspassia Chatziefthimiou, ${ }^{1}$ \\ Ramaydalis Cruz-Matos, ${ }^{1,2}$ Ileana Pérez-Rodríguez, ${ }^{1,2}$ Tamar Barkay, ${ }^{1}$ \\ Richard A. Lutz, ${ }^{2}$ Valentin Starovoytov ${ }^{3}$ and Costantino Vetriani ${ }^{1,2}$ \\ ${ }^{1}$ Department of Biochemistry and Microbiology, Rutgers University, New Brunswick, NJ 08901, \\ USA \\ ${ }^{2}$ Institute of Marine and Coastal Sciences, Rutgers University, New Brunswick, NJ 08901, USA \\ ${ }^{3}$ Department of Cell Biology and Neuroscience, Rutgers University, Piscataway, NJ 08854, USA
}

Deep-sea hydrothermal vents are located in tectonically active areas of the sea floor and release either hightemperature fluids (focused-flow vents) or moderatetemperature fluids (diffuse-flow vents). At deep-sea vents,

\footnotetext{
Abbreviations: EPR, East Pacific Rise; RuBisCO, ribulose-1,5-bisphosphate carboxylase/oxygenase.

The GenBank/EMBL/DDBJ accession numbers for the $16 \mathrm{~S}$ rRNA gene sequences of strains EPR70 ${ }^{\top}$, EPR72 and EPR71 are EU740416EU740418. The accession numbers for the partial $r b c L$ gene sequences from strains EPR70', EPR71 and EPR72 and S. shabanensis DSM $14853^{\top}$ are EU740422-EU740425 and those for the partial alkB gene sequences of strain EPR $70^{\top}$, S. shabanensis DSM $14853^{\top}$ and strain EPR71 are EU740419-EU740421.

Graphs showing the effects of temperature, $\mathrm{pH}$ and $\mathrm{NaCl}$ concentration on growth of strain EPR70 ${ }^{\top}$ and neighbour-joining trees based on amino acid sequences of RuBisCO form I and AlkB are available as supplementary material with the online version of this paper.
}

seawater interacts with volcanic rocks at high temperature and becomes enriched in a variety of reduced chemical species, which represent a constant flux of electron donors for microbial oxidations. In the absence of light, chemosynthetic micro-organisms oxidize these reduced chemical species (predominantly sulfur compounds) and mediate the primary production of organic carbon (Jannasch, 1995; McCollom \& Shock, 1997).

Typically, representatives of the genera Thiomicrospira and Thiobacillus have been isolated when diffuse-flow hydrothermal fluids were inoculated in culture media for the enrichment of chemosynthetic, aerobic, sulfide-, sulfur- and thiosulfate-oxidizing bacteria (Ruby et al., 1981; Ruby \& Jannasch, 1982; Jannasch et al., 1985; Durand et al., 1993; Teske et al., 2000; Takai et al., 2004). Heterotrophic bacteria of the genera Marinobacter, Vibrio, Pseudoalteromonas and Halomonas, among others, have also been isolated routinely 
from hydrothermal vent samples (Raguénès et al., 1997; Teske et al., 2000; Kaye et al., 2004; Vetriani et al., 2005; Simon-Colin et al., 2008) and their abundance in vent fluids collected from the Pacific Ocean was estimated to be up to $28 \%$ of the total micro-organisms (Kaye \& Baross, 2000).

Here, we report the isolation of three strains of mesophilic, halotolerant, facultatively chemolithoautotrophic, thiosulfate-oxidizing gammaproteobacteria from deep-sea hydrothermal vents located on the East Pacific Rise (EPR) at $9^{\circ} \mathrm{N}$ and the characterization of one of these strains.

Hydrothermal fluid samples from diffuse-flow vents were collected from the EPR $\left(9^{\circ} 50^{\prime} \mathrm{N} 104^{\circ} 17^{\prime} \mathrm{W}\right)$ at a depth of approximately $2500 \mathrm{~m}$ during an oceanographic expedition aboard the R/V Atlantis in April 2004. The fluids were collected using titanium samplers operated by the manipulator of the DSV Alvin, immediately above the venting source and $1 \mathrm{~m}$ above the source. On the surface, samples were transferred promptly to the ship's laboratory and subsamples were stored at $4{ }^{\circ} \mathrm{C}$. Primary enrichment cultures were initiated immediately after sample collection in growth medium designed to enrich for chemolithoautotrophic, thiosulfate-oxidizing bacteria. The medium used was a modification of medium 142 (http://www.dsmz.de), referred to as $142-\mathrm{A}$, which was composed of $\left(\mathrm{l}^{-1}\right): \mathrm{NaCl}, 25.0 \mathrm{~g}$; $\left(\mathrm{NH}_{4}\right)_{2} \mathrm{SO}_{4}, 1.0 \mathrm{~g} ; \mathrm{MgSO}_{4} .7 \mathrm{H}_{2} \mathrm{O}, 1.5 \mathrm{~g} ; \mathrm{CaCl}_{2} .2 \mathrm{H}_{2} \mathrm{O}$, 0.42 g; $\mathrm{KCl}, 0.64$ g; $\mathrm{NaHCO}_{3}, 0.046$ g; $\mathrm{K}_{2} \mathrm{HPO}_{4}, 0.05$ g. Two millilitres of a $0.5 \%$ phenol red solution was added to 11 medium as a pH indicator. Following sterilization, the medium was supplemented with $20 \mathrm{mM} \mathrm{Na} \mathrm{N}_{2} \mathrm{O}_{3}, 1 \mu \mathrm{M}$ vitamin $\mathrm{B}_{12}, 1 \mathrm{ml}$ mixed vitamin solution 141 (http:// www.dsmz.de) and $1 \mathrm{ml}$ trace-element solution SL10 (http://www.dsmz.de). For isolation of single colonies, liquid cultures were inoculated on Petri dishes containing medium 142-A solidified with $15 \mathrm{~g}$ Noble agar $\mathrm{l}^{-1}$ (Sigma). Stocks for long-term storage were prepared by adding $150 \mu \mathrm{l}$ sterile glycerol (Fisher Scientific) to $850 \mu \mathrm{l}$ culture grown overnight, and were stored at $-80{ }^{\circ} \mathrm{C}$.

Heterotrophic growth was determined by transferring $100 \mu \mathrm{l}$ of an overnight culture from medium $142-\mathrm{A}$ to medium $142+\mathrm{A}$, which was depleted of $\mathrm{NaHCO}_{3}$ and supplemented with $10 \mathrm{mM}$ sodium acetate (Sigma). Growth was also tested in artificial seawater (ASW) medium $\left(1^{-1}: \mathrm{NaCl}, 24 \mathrm{~g} ; \mathrm{KCl}, 0.7 \mathrm{~g} ; \mathrm{MgCl}_{2}, 7.0\right.$ g; yeast extract, $3.0 \mathrm{~g}$; peptone, $2.5 \mathrm{~g}$ ), in low-strength ASW (LS ASW) medium (modified ASW containing $0.1 \mathrm{~g}$ yeast extract and $0.5 \mathrm{~g}$ peptone $1^{-1}$ ) and in ASW minimal medium (ASW MM) $\left(\mathrm{l}^{-1}: \mathrm{NaCl}, 23.6 \mathrm{~g} ; \mathrm{KCl}, 0.64 \mathrm{~g}\right.$; $\mathrm{MgCl}_{2} .6 \mathrm{H}_{2} \mathrm{O}, 4.53 \mathrm{~g} ; \mathrm{MgSO}_{4} .7 \mathrm{H}_{2} \mathrm{O}, 5.94 \mathrm{~g} ; \mathrm{CaCl}_{2} \cdot 2 \mathrm{H}_{2} \mathrm{O}$, 1.3 g) $\mathrm{Na}_{2} \mathrm{HPO}_{4} .7 \mathrm{H}_{2} \mathrm{O}, 43.0 \mathrm{mg} ; \mathrm{NaNO}_{3}, 0.22 \mathrm{~g} ; \mathrm{NH}_{4} \mathrm{Cl}$, $0.65 \mathrm{~g})$ supplemented with dodecane $\left(\mathrm{C}_{12} \mathrm{H}_{26}\right)$ in the vapour phase as the only carbon and energy source. After autoclaving, ASW MM was supplemented with $1 \mu \mathrm{M}$ vitamin $B_{12}, 1 \mathrm{ml}$ trace-element solution SL-10 and $1 \mathrm{ml}$ mixed vitamin solution 141 .

Growth rates $\left(\mu ; \mathrm{h}^{-1}\right)$ were estimated as described previously (Vetriani et al., 2004). Unless specified otherwise, growth ranges and optimal growth conditions were determined in LS ASW medium. To determine the optimal growth temperature of the new isolate, cultures were incubated between 10 and $45{ }^{\circ} \mathrm{C}$ (at $5{ }^{\circ} \mathrm{C}$ intervals). All other experiments were carried out at $35{ }^{\circ} \mathrm{C}$, the optimal growth temperature. To determine optimal salt requirements, the concentration of $\mathrm{NaCl}$ was varied between 1.0 and $25 \%(\mathrm{w} / \mathrm{v})$. The influence of $\mathrm{pH}$ on growth was determined between $\mathrm{pH} 4.5$ and 8.0 by using the following buffers at a concentration of $10 \mathrm{mM}$ : acetate at $\mathrm{pH} 4.5$ and 5.0; MES at $\mathrm{pH} 5.5$ and 6.0; PIPES at $\mathrm{pH}$ 6.5, 7.0 and 7.5; and Tris at $\mathrm{pH}$ 8.0. Anaerobic growth with nitrate as an electron acceptor was tested in ASW medium supplemented with $7.3 \mathrm{mM} \mathrm{KNO}_{3}$ under a $\mathrm{N}_{2}$ atmosphere.

Catalase activity was determined as described previously (Vetriani et al., 2004) and the presence of cytochrome $c$, a component of the cytochrome oxidase system, was determined according to the protocol described by Kovacs (1956). Escherichia coli K-12 and Pseudomonas aeruginosa were used as negative and positive controls for the cytochrome oxidase test, respectively.

A Biolog GN2 MicroPlate test panel was used to compare the carbon utilization/oxidation profiles of the new isolate with that of the reference strain, Salinisphaera shabanensis DSM $14853^{\mathrm{T}}$. Confluent growth of both strains was obtained on solid ASW medium overnight. Cells were collected using a sterile cotton swab and resuspended in $15 \mathrm{ml}$ salt solution $\left(\mathrm{l}^{-1}: \mathrm{NaCl}, 23.5 \mathrm{~g} ; \mathrm{MgCl}_{2} .6 \mathrm{H}_{2} \mathrm{O}\right.$, $10.6 \mathrm{~g}$ ). The cell suspension was adjusted to an $\mathrm{OD}_{600}$ of $0.3 \pm 0.05$, supplemented with $5 \mathrm{mM}$ sodium thioglycolate and dispensed (in $150 \mu \mathrm{l}$ aliquots) to each well of two Biolog GN2 MicroPlates, which were incubated at $35^{\circ} \mathrm{C}$. A change in colour, indicative of the oxidation of the substrate, was monitored for $48 \mathrm{~h}$.

For direct counts, cells were stained routinely with $0.1 \%$ acridine orange and visualized with an Olympus BX 60 microscope with an oil-immersion objective lens (UplanF1 $\times 100 / 1.3)$. Cells for ultrathin sections and for platinum shadowing were prepared as described previously (Vetriani et al., 2004). Motility was determined by phase-contrast microscopy. Gram staining was performed as described elsewhere (Holt et al., 1994).

Genomic DNA was extracted from cells collected by centrifugation using the UltraClean Microbial DNA isolation kit, according to the manufacturer's instructions (MoBio Laboratories). The full-length sequence of the 16S rRNA gene was selectively amplified from the genomic DNA by PCR, cloned, sequenced and subjected to phylogenetic analysis as described previously (Vetriani et al., 2004; Voordeckers et al., 2005).

The genes encoding the enzymes ribulose-1,5-bisphosphate carboxylase/oxygenase form I and II (RuBisCO) and alkane hydroxylase (AlkB, involved in the oxidation of hydrocarbons) were amplified from the genomic DNA of the novel strains and S. shabanensis DSM $14853^{\mathrm{T}}$. A $500 \mathrm{bp}$ 
fragment of the gene encoding form I RuBisCO $(r b c L / c b b L)$ from S. shabanensis DSM $14853^{\mathrm{T}}$ was amplified as described previously (Nanba et al., 2004), and its sequence was determined. Internal primers ss rbcLF (5'GGTCTATGAAAGCGCTCAAGG-3') and ss rbcLR (5'ATCCATTTCGAGATCACGCGG-3' ${ }^{\prime}$ ) were designed based on the $r b c L$ sequence from $S$. shabanensis DSM $14853^{\mathrm{T}}$ (using the IDT OligoAnalyser 3.1 program; http:// www.idtdna.com), and were used to amplify a $400 \mathrm{bp}$ fragment of the $r b c L$ gene from the three novel strains. The PCR protocol used to amplify the $r b c L$ genes was $5 \mathrm{~min}$ at $94{ }^{\circ} \mathrm{C}$ followed by 30 cycles of $45 \mathrm{~s}$ at $94{ }^{\circ} \mathrm{C}, 1 \mathrm{~min}$ at $50{ }^{\circ} \mathrm{C}$ and $45 \mathrm{~s}$ at $72{ }^{\circ} \mathrm{C}$, ending with a final extension of $20 \mathrm{~min}$ at $72{ }^{\circ} \mathrm{C}$. The PCR for the amplification of a $1040 \mathrm{bp}$ fragment of the gene encoding the form II RuBisCO $(c b b M)$ was carried out as described previously (Elsaied et al., 2007). A $550 \mathrm{bp}$ fragment of the gene encoding alkane hydroxylase (alkB) was amplified selectively from the genomic DNA of S. shabanensis DSM $14853^{\mathrm{T}}$ and of two of the novel strains by PCR, as described previously (Smits et al., 1999). The sequences for $r b c L$ and alkB were determined for both strands and were translated into the respective amino acid sequences using EMBOSS Transeq (http://www.ebi.ac.uk/emboss/transeq). The amino acid sequences were aligned with CLUSTAL_X v. 1.8 (Thompson et al., 1997) and adjusted manually using SeaView (Galtier et al., 1996). Phylogenetic distances were calculated using the Observed Divergence matrix and the neighbour-joining method was used to evaluate tree topologies. PHYLO_WIN was used to plot tree topologies (Galtier et al., 1996) and their robustness was tested by bootstrap analysis with 1000 resamplings. The determination of total DNA base composition $(\mathrm{mol} \% \mathrm{G}+\mathrm{C})$ was carried out by HPLC (Mesbah et al., 1989).

Enrichment cultures for mesophilic, chemolithoautotrophic, thiosulfate-oxidizing bacteria were obtained by inoculating $10 \mathrm{ml}$ medium $142-\mathrm{A}$ with $1 \mathrm{ml}$ fluid from three different samples collected on the EPR. The temperature of the fluids at the time of collection was $2.5,6$ and $13{ }^{\circ} \mathrm{C}$, respectively. Cultures were incubated at $30{ }^{\circ} \mathrm{C}$. A change in colour of the $\mathrm{pH}$ indicator present in the medium, suggesting growth, was observed after 1 or 2 days from the beginning of the incubation and then confirmed by direct cell counting. Three independent cultures showed consistent growth after repeated transfers and were purified by successive isolations of single colonies on solidified medium. The resulting pure cultures were designated strains EPR70 ${ }^{\mathrm{T}}$, EPR71 and EPR72. Preliminary phylogenetic analysis of the 16S rRNA gene sequence indicated that the three strains were closely related (sequence identity $99 \%$ ). Strain EPR70 ${ }^{\mathrm{T}}$ was selected for further characterization.

Cells of EPR70 ${ }^{\mathrm{T}}$ were short rods, $0.8-1.0 \mu \mathrm{m}$ long and $0.3-$ $0.5 \mu \mathrm{m}$ wide, and divided by constriction (Fig. 1a). Cells stained Gram-negative. The cell envelope of EPR $70^{\mathrm{T}}$ included a cytoplasmic membrane surrounded by a periplasmic space and an outer membrane (Fig. 1b). The

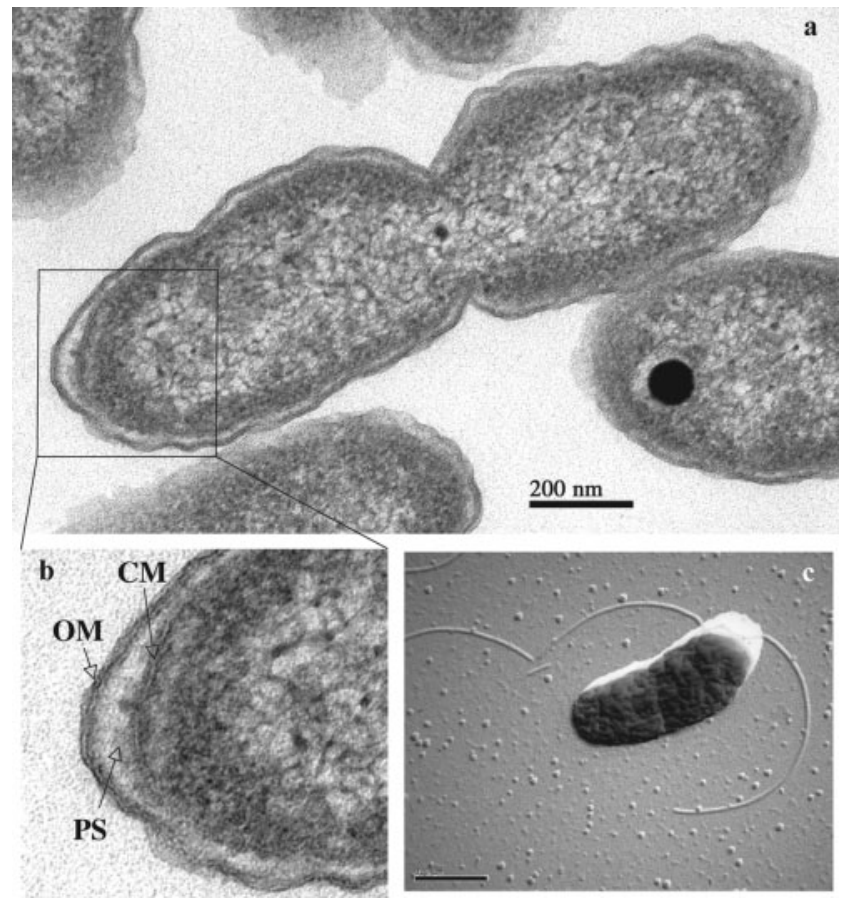

Fig. 1. (a) Electron micrograph of a thin section of cells of strain EPR70 ${ }^{\top}$. (b) Details of the cell envelope of strain EPR70 ${ }^{\top}$. OM, Outer membrane; PS, periplasmic space; CM, cytoplasmic membrane. (c) Electron micrograph of a platinum-shadowed cell of strain EPR70 ${ }^{\top}$ showing the presence of flagella. Bars, $200 \mathrm{~nm}$ (a) and $0.5 \mu \mathrm{m}$ (c).

organism was motile and possessed one or more flagella, which were observed in electron micrographs of platinumshadowed cells (Fig. 1c). The presence of endospores was not observed.

Under strictly autotrophic conditions, EPR70 ${ }^{\mathrm{T}}$, EPR71 and EPR72 oxidized $\mathrm{Na}_{2} \mathrm{~S}_{2} \mathrm{O}_{3}$ and acidified the culture medium. Heterotrophic growth occurred when medium 142 was depleted of $\mathrm{Na}_{2} \mathrm{~S}_{2} \mathrm{O}_{3}$ and $\mathrm{NaHCO}_{3}$ and supplemented with $10 \mathrm{mM}$ acetate; under these conditions, strain EPR70 $^{\mathrm{T}}$ alkalified the culture medium. EPR70 ${ }^{\mathrm{T}}$, EPR71 and EPR72 also grew well heterotrophically in ASW, LS ASW and ASW MM supplemented with dodecane as the sole carbon and energy source. Strain $E P R 70^{\mathrm{T}}$ grew at temperatures between 20 and $40{ }^{\circ} \mathrm{C}$, with optimal growth at $35{ }^{\circ} \mathrm{C}$. No growth was detected at 10 or $45{ }^{\circ} \mathrm{C}$. EPR7 ${ }^{\mathrm{T}}$ grew at $\mathrm{NaCl}$ concentrations between 1.0 and $25.0 \%(\mathrm{w} / \mathrm{v})$ with an optimum at $2.5 \%(\mathrm{w} / \mathrm{v})$. Growth occurred between pH 5.0 and 7.5 with an optimum at $\mathrm{pH}$ 5.5. No growth was observed at $\mathrm{pH} 4.5$ or 8.0. The shortest generation time of strain EPR70 ${ }^{\mathrm{T}}$ in LS ASW was $42 \mathrm{~min}$ (Supplementary Fig. S1, available in IJSEM Online). For comparison, the generation time of strain $E P R 70^{\mathrm{T}}$ grown under optimal conditions of temperature, salinity and $\mathrm{pH}$ and with $\mathrm{CO}_{2}$ as the sole carbon source (in medium 142) was 231 min. Strain EPR70 ${ }^{\mathrm{T}}$ was a fully aerobic organism, 
and growth did not occur in medium 142 supplemented with $5 \%$ oxygen $(\mathrm{v} / \mathrm{v})$ or in ASW medium with $7.3 \mathrm{mM}$ nitrate.

Phylogenetic analysis of the 16S rRNA gene sequence, carried out using the neighbour-joining method, placed EPR70 $^{\mathrm{T}}$, EPR71 and EPR72 (98-99\% sequence identity between each sequence) in a unique cluster within the class Gammaproteobacteria (Fig. 2). The closest relatives of these strains were S. shabanensis E1L3A ${ }^{\mathrm{T}}$, a moderate halophile which was isolated from the brine-seawater interface in the Shaban Deep in the Red Sea (94\% sequence identity to the $16 \mathrm{~S}$ rRNA gene of strain EPR70 ${ }^{\mathrm{T}}$ ) and which is the only formally described member of this genus (Antunes et al., 2003), Salinisphaera sp. strain ARD M17, isolated from deep-sea water from the Knipovich Ridge, in the Arctic Ocean $\left(94 \%\right.$ sequence identity to strain EPR70 ${ }^{\mathrm{T}}$ ) (T. Okamoto and T. Naganuma, unpublished; GenBank accession no. AB167073), and 'Salinisphaera dokdoensis' CL-ES53, isolated from the East Sea of Korea (95\% sequence identity to strain EPR70 ${ }^{\mathrm{T}}$ ) (B. C. Cho and others, unpublished; EF988634). While the type species of the genus Salinisphaera, S. shabanensis, was originally described as a heterotroph (Antunes et al., 2003), our study demonstrated that this organism also grew chemolithoautotrophically by thiosulfate oxidation and with nalkanes as the sole carbon and energy source (Table 1). Interestingly, $16 \mathrm{~S}$ rRNA gene sequences related to Salinisphaera species were retrieved from the microbial community attached to hydrocarbon-contaminated rocks along the Spanish shoreline, represented in Fig. 2 by clones Rc23, Rc32 and Rc58 (J. Alonso-Gutierrez and others, unpublished).

High bootstrap values supported the branching topology of the EPR strains relative to the other strains (Fig. 2). The $\mathrm{G}+\mathrm{C}$ content of the genomic DNA of strain EPR70 ${ }^{\mathrm{T}}$, determined by HPLC analysis of deoxyribonucleosides, was $64.0 \mathrm{~mol} \%$, while that of $S$. shabanensis $\mathrm{E} 1 \mathrm{~L} 3 \mathrm{~A}^{\mathrm{T}}$ was $61.8 \mathrm{~mol} \%$ (Antunes et al., 2003).

Comparative analyses of strain EPR7 $70^{\mathrm{T}}$ and S. shabanensis DSM $14853^{\mathrm{T}}$ revealed morphological (rods and cocci, respectively) and physiological differences (Table 1). In particular, EPR $70^{\mathrm{T}}$ had lower salinity and $\mathrm{pH}$ optima than S. shabanensis DSM $14853^{\mathrm{T}}$ (2.5 vs $10 \% \mathrm{NaCl}$ and $\mathrm{pH} 5.5$ vs $\sim \mathrm{pH} 7.0$, respectively), suggesting specific adaptations to the slightly acidic vent fluids, and strain EPR7 ${ }^{\mathrm{T}}$ could not grow anaerobically in the presence of nitrate as a terminal electron acceptor (Table 1). The metabolic fingerprints of strain EPR70 ${ }^{\mathrm{T}}$ and S. shabanensis DSM $14853^{\mathrm{T}}$, determined using a Biolog assay on a GN2 MicroPlate, showed that both bacteria were able to oxidize a wide range of carbon sources, but some differences were evident (Table 2). For instance, EPR70 $0^{\mathrm{T}}$ oxidized sugars and sugar alcohols preferentially, while $S$. shabanensis preferred amino acid derivatives.

In order to investigate the carbon-fixation pathway in the EPR strains and in S. shabanensis DSM $14853^{\mathrm{T}}$, we carried out PCR amplification of the genes encoding both RuBisCO forms I $(r b c L / c b b L)$ and II $(c b b M)$ for all strains, and a product was obtained only for the $r b c L / c b b L$ gene (encoding RuBisCO form I). The amino acid identity among the RuBisCO sequences of the three EPR strains was 98-99\%, while the sequence identity between these enzymes and the RuBisCO from $S$. shabanensis DSM $14853^{\mathrm{T}}$ ranged from 94 to $95 \%$. Phylogenetic analysis of the amino acid sequence of the form I RuBisCO of strains $\mathrm{EPR70}^{\mathrm{T}}, \mathrm{EPR71}$ and EPR72 and S. shabanenesis DSM $14853^{\mathrm{T}}$, carried out using the neighbour-joining method, showed that these sequences formed a unique cluster related to other form I, type C enzymes (Supplementary Fig. S2; Xu \& Tabita, 1996). The closest relatives of the

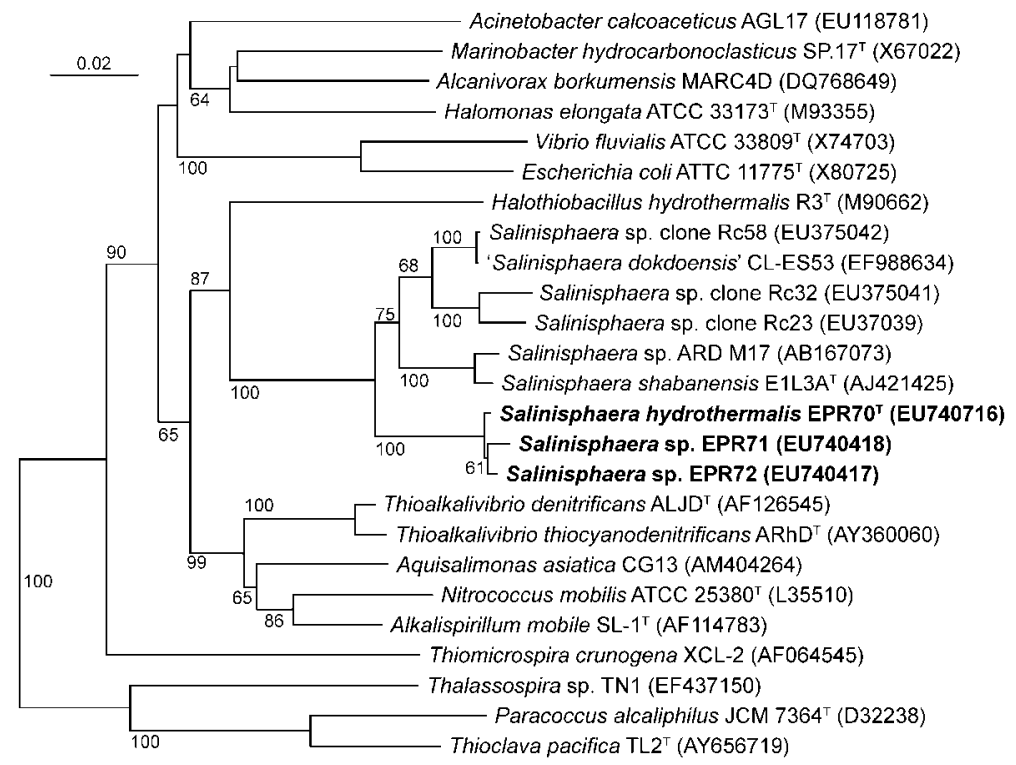

Fig. 2. Phylogenetic position of strains EPR70 $^{\top}$, EPR71 and EPR72, according to their $16 \mathrm{~S}$ rRNA gene sequences. The neighbour-joining tree was constructed using PHYLO_WIN. Bootstrap values higher than $50 \%$ are indicated. Bar, $2 \%$ estimated base substitutions. 
Table 1. Differentiating features of strain EPR $70^{\top}$ and S. shabanensis E1L3A ${ }^{\top}$

Both strains are catalase-positive. Data for S. shabanensis E1L3A ${ }^{\mathrm{T}}$ were taken from Antunes et al. (2003) unless indicated.

\begin{tabular}{|lcc|}
\hline Feature & Strain EPR70 & S. shabanensis E1L3A \\
\hline Morphology & Small rods & Cocci \\
Cell size $(\mu \mathrm{m})$ & $0.8-1.0 \times 0.3-0.5$ & $0.7-1.2$ (diameter) \\
Oxidase & Negative & Positive \\
Temperature for growth $\left({ }^{\circ} \mathrm{C}\right)$ & & \\
$\quad$ Range & $20-40$ & $5-42$ \\
Optimum & $30-35$ & $30-37$ \\
Salinity for growth $(\% \mathrm{NaCl})$ & & \\
Range & $1-25$ & $1-28$ \\
Optimum & 2.5 & 10 \\
pH for growth & & $4.0-8.0$ \\
Range & $5.0-7.5$ & $6.5-7.5$ \\
Optimum & 5.5 & Yes \\
Chemolithoautotrophic growth & Yes & Yes* \\
Growth on dodecane & Yes & Yes \\
Anaerobic growth in ASW plus nitrate & No & 61.8 \\
DNA G + C content $(m o l \%)$ & 64.0 & \\
\hline
\end{tabular}

${ }^{\star}$ Data for S. shabanensis DSM $14853^{\mathrm{T}}$ obtained in this study.

RuBisCO from the EPR strains and S. shabanenesis DSM $14853^{\mathrm{T}}$ were the enzymes of the methylotrophic bacterium Methylibium petroleiphilum $\mathrm{PM}^{\mathrm{T}}$ and of the ammoniaoxidizing bacteria Nitrosospira multiformis ATCC $25196^{\mathrm{T}}$ and Nitrosococcus oceani ATCC $19707^{\mathrm{T}}$ (Supplementary Fig. S2). It is worth noting that the RuBisCO enzymes from the EPR strains were also related to a group of sequences retrieved from natural microbial communities associated with the plumes of black smokers located in the Western Pacific arc hydrothermal vent system, represented in Supplementary Fig. S2 by clones ICS1 and ICP1 (Elsaied et al., 2007).

Since both the EPR strains and S. shabanensis DSM $14853^{\mathrm{T}}$ can use n-alkanes as their sole carbon and energy source, we investigated the presence in these organisms of the alkB gene, which encodes alkane hydroxylase (AlkB), an enzyme that catalyses the first step in the oxidation of hydrocarbons. Phylogenetic analysis of the amino acid sequence of the AlkB enzyme from strains EPR70 ${ }^{\mathrm{T}}$, EPR71 and S. shabanensis DSM $14853^{\mathrm{T}}$ placed these enzymes in a discrete cluster related to the alkane hydroxylase of Nocardia farcinia IFM 10152 (Supplementary Fig. S3). The identity between the AlkB amino acid sequences of EPR70 ${ }^{\mathrm{T}}$ and EPR71 was $90 \%$, while the sequence identities of the enzymes from the two EPR strains and the alkane hydroxylase from $S$. shabanensis DSM $14853^{\mathrm{T}}$ were 62 and $63 \%$, respectively.

Physiological and phylogenetic analyses indicated that strain EPR70 ${ }^{\mathrm{T}}$ and S. shabanensis DSM $14853^{\mathrm{T}}$ are not related at the species level, and therefore EPR70 ${ }^{\mathrm{T}}$ represents a new species within the genus Salinisphaera, for which we propose the name Salinisphaera hydrothermalis sp. nov.

At deep-sea hydrothermal vents, micro-organisms must adapt to highly dynamic environmental conditions, where there are fluctuations in temperature, salinity and nutrient availability (Karl, 1995). The presence of the $r b c L / c b b L$ gene, which encodes RuBisCO form I, in all the Salinisphaera strains suggests strongly that these bacteria use the Calvin-Benson-Bassham cycle to fix $\mathrm{CO}_{2}$. The metabolic versatility of $S$. hydrothermalis, which can fix $\mathrm{CO}_{2}$ and use a wide range of organic carbon sources, may be an advantage for its growth and survival in these environments. In particular, the ability of S. hydrothermalis to grow autotrophically, to oxidize n-alkanes (which are enriched in hydrothermal fluids; Brault et al., 1988) and to grow optimally at a slightly acidic $\mathrm{pH}$ suggests that this bacterium is particularly well suited to thrive in the moderate-temperature fluids that are typically emitted by diffuse-flow deep-sea hydrothermal vents.

\section{Emended description of the genus Salinisphaera Antunes et al. 2003}

Cells are Gram-negative cocci or short rods, possessing one or more flagella. Mesophilic, halotolerant and catalasepositive. Aerobic or facultatively anaerobic. Growth occurs chemolithoautotrophically with thiosulfate as an electron donor and oxygen as an electron acceptor, heterotrophically on n-alkanes (dodecane) as the sole carbon and energy source or on complex media. Known strains have been found in marine environments. The type species is Salinisphaera shabanensis Antunes et al. 2003.

\section{Description of Salinisphaera hydrothermalis sp. nov.}

Salinisphaera hydrothermalis (hy.dro.ther.ma'lis. N.L. fem. adj. hydrothermalis hydrothermal, pertaining to a hydrothermal vent). 
Table 2. Comparative metabolic profiles of strain $E P R 70^{\top}$ and S. shabanensis DSM $14853^{\top}$

Both strains oxidized Tweens 20 and 80, D-mannitol, D-mannose, xylitol, pyruvic acid methyl ester, succinic acid monomethyl ester, $\gamma$ hydroxybutyric acid, DL-lactic acid, succinic acid and L-alanine. Data were obtained in this study using the Biolog GN2 MicroPlate.

\begin{tabular}{|c|c|c|}
\hline Carbon source & Strain EPR70 ${ }^{\mathrm{T}}$ & $\begin{array}{c}\text { S. shabanensis DSM } \\
14853^{\mathrm{T}}\end{array}$ \\
\hline Glycogen & - & + \\
\hline Adonitol & + & - \\
\hline D-Arabitol & + & - \\
\hline i-Erythritol & + & - \\
\hline D-Fructose & + & - \\
\hline D-Galactose & + & - \\
\hline$\alpha$-D-Glucose & + & - \\
\hline L-Rhamnose & + & - \\
\hline D-Sorbitol & + & - \\
\hline cis-Aconitic acid & - & + \\
\hline Formic acid & - & + \\
\hline$\alpha$-Ketobutyric acid & + & - \\
\hline$\alpha$-Ketoglutaric acid & - & + \\
\hline Bromosuccinic acid & - & + \\
\hline Succinamic acid & + & - \\
\hline L-Alanyl glycine & - & + \\
\hline L-Asparagine & - & + \\
\hline L-Aspartic acid & - & + \\
\hline L-Glutamic acid & - & + \\
\hline Glycyl L-aspartic acid & - & + \\
\hline Glycyl L-glutamic acid & - & + \\
\hline L-Proline & + & - \\
\hline$\gamma$-Aminobutyric acid & + & - \\
\hline Glycerol & + & - \\
\hline
\end{tabular}

Cells are small rods $(0.8-1.0 \mu \mathrm{m}$ long, $0.3-0.5 \mu \mathrm{m}$ wide), which are motile by means of one or more flagella. Obligate aerobe. Oxidase-negative. Growth occurs at $20-40{ }^{\circ} \mathrm{C}$ (optimum $30-35{ }^{\circ} \mathrm{C}$ ), $1-25 \% \mathrm{NaCl}$ (optimum $2.5 \%$ ) and $\mathrm{pH}$ 5.0-7.5 (optimum $\mathrm{pH}$ 5.5). The shortest generation time observed is $42 \mathrm{~min}$. Growth occurs under aerobic, chemolithoautotrophic conditions in the presence of thiosulfate and $\mathrm{CO}_{2}$. Heterotrophic growth occurs with acetate or n-alkanes as sole carbon and energy sources and in complex ASW medium. Nitrate is not used as an electron acceptor. The DNA G+C content of the type strain is $64.0 \mathrm{~mol} \%$ as determined by the HPLC method.

The type strain is EPR70 $0^{\mathrm{T}}\left(=\mathrm{DSM} 21483^{\mathrm{T}}=\mathrm{JCM} 15514^{\mathrm{T}}\right)$, which was isolated from diffuse-flow hydrothermal vent fluids collected from the East Pacific Rise at $9^{\circ} 50^{\prime} \mathrm{N}$.

\section{Acknowledgements}

We wish to thank Amber G. Jensen for excellent technical assistance. We thank the crew of the R/V Atlantis and the crew and pilots of the
DSV Alvin for their skilled operation at sea. This research was supported by NSF grant OCE 03-27353 to C.V. and R. A. L., NSF grant MCB 04-56676 to C. V., NSF grant EAR 04-33793 to T. B., and by NIH R25GM-58389 and an NSF Graduate Research Fellowship to M. C.-M.

\section{References}

Antunes, A., Eder, W., Fareleira, P., Santos, H. \& Huber, R. (2003). Salinisphaera shabanensis gen. nov., sp. nov., a novel, moderately halophilic bacterium from the brine-seawater interface of the Shaban Deep, Red Sea. Extremophiles 7, 29-34.

Brault, M., Simoneit, B. R. T., Marty, J. C. \& Saliot, A. (1988). Hydrocarbons in waters and particulate material from hydrothermal environments at the East Pacific Rise, $13^{\circ}$ N. Org Geochem 12, 209 219.

Durand, P., Reysenbach, A. L., Prieur, D. \& Pace, N. (1993). Isolation and characterization of Thiobacillus hydrothermalis sp. nov., a mesophilic obligately chemolithotrophic bacterium isolated from a deep-sea vent in Fiji Basin. Arch Microbiol 159, 39-44.

Elsaied, H. E., Kimura, H. \& Naganuma, T. (2007). Composition of archaeal, bacterial, and eukaryal RuBisCO genotypes in three Western Pacific arc hydrothermal vent systems. Extremophiles 11, 191-202.

Galtier, N., Gouy, M. \& Gautier, C. (1996). SeaView and PHYLO_WIN, two graphic tools for sequence alignment and molecular phylogeny. Comput Appl Biosci 12, 543-548.

Holt, J. G., Krieg, N. R., Sneath, P. H. A., Staley, J. T. \& Williams, S. T. (1994). Bergey's Manual of Determinative Bacteriology, 9th edn. Baltimore: Williams \& Wilkins.

Jannasch, H. W. (1995). Microbial interactions with hydrothermal fluids. In Seafloor Hydrothermal Systems: Physical, Chemical, Biological and Geological Interactions, pp. 273-296. Edited by S. E. Humphris, R. A. Zierenberg, L. S. Mullineaux \& R. E. Thomson. Washington, DC: American Geophysical Union.

Jannasch, H. W., Wirsen, C. O., Nelson, D. C. \& Robertson, L. A. (1985). Thiomicrospira crunogena sp. nov., a colorless sulfur-oxidizing bacterium from a deep-sea hydrothermal vent. Int J Syst Bacteriol 35, 422-424.

Karl, D. M. (1995). Ecology of free-living, hydrothermal vent microbial communities. In The Microbiology of Deep-Sea Hydrothermal Vents, pp. 35-124. Edited by D. M. Karl. Boca Raton, FL: CRC Press.

Kaye, J. Z. \& Baross, J. A. (2000). High incidence of halotolerant bacteria in Pacific hydrothermal-vent and pelagic environments. FEMS Microbiol Ecol 32, 249-260.

Kaye, J. Z., Marquez, M. C., Ventosa, A. \& Baross, J. A. (2004). Halomonas neptunia sp. nov., Halomonas sulfidaeris sp. nov., Halomonas axialensis sp. nov. and Halomonas hydrothermalis sp. nov.: halophilic bacteria isolated from deep-sea hydrothermal-vent environments. Int J Syst Evol Microbiol 54, 499-511.

Kovacs, N. (1956). Identification of Pseudomonas pyocyanea by the oxidase reaction. Nature 178, 703.

McCollom, T. M. \& Shock, E. L. (1997). Geochemical constraints on chemolithoautotrophic metabolisms by microorganisms in seafloor hydrothermal systems. Geochim Cosmochim Acta 61, 4375-4391.

Mesbah, M., Premachandran, U. \& Whitman, W. B. (1989). Precise measurement of the $\mathrm{G}+\mathrm{C}$ content of deoxyribonucleic acid by highperformance liquid chromatography. Int J Syst Bacteriol 39, 159-167.

Nanba, K., King, G. M. \& Dunfield, K. (2004). Analysis of facultative lithotroph distribution and diversity on volcanic deposits by use of 
the large subunit of ribulose 1,5-bisphosphate carboxylase/oxygenase. Appl Environ Microbiol 70, 2245-2253.

Raguénès, G., Christen, R., Guezennec, J., Pignet, P. \& Barbier, G. (1997). Vibrio diabolicus sp. nov., a new polysaccharide-secreting organism isolated from a deep-sea hydrothermal vent polychaete annelid, Alvinella pompejana. Int J Syst Bacteriol 47, 989-995.

Ruby, E. G. \& Jannasch, H. W. (1982). Physiological characteristics of Thiomicrospira sp. strain L-12 isolated from deep-sea hydrothermal vents. J Bacteriol 149, 161-165.

Ruby, E. G., Wirsen, C. O. \& Jannasch, H. W. (1981). Chemolithotrophic sulfur-oxidizing bacteria from the Galapagos rift hydrothermal vents. Appl Environ Microbiol 42, 317-324.

Simon-Colin, C., Raguénès, G., Cozien, J. \& Guezennec, J. G. (2008). Halomonas profundus sp. nov., a new PHA-producing bacterium isolated from a deep-sea hydrothermal vent shrimp. J Appl Microbiol 104, 1425-1432.

Smits, T. H. M., Röthlisberger, M., Witholt, B. \& van Beilen, J. B. (1999). Molecular screening for alkane hydroxylase genes in Gramnegative and Gram positive strains. Environ Microbiol 1, 307-317.

Takai, K., Hirayama, H., Nakagawa, T., Suzuki, Y., Nealson, K. H. \& Horikoshi, K. (2004). Thiomicrospira thermophila sp. nov., a novel microaerobic, thermotolerant, sulfur-oxidizing chemolithomixotroph isolated from a deep-sea hydrothermal fumarole in the TOTO caldera, Mariana Arc, Western Pacific. Int J Syst Evol Microbiol 54, 2325-2333.
Teske, A., Brinkhoff, T., Muyzer, G., Moser, D. P., Rethmeier, J. \& Jannasch, H. W. (2000). Diversity of thiosulfate-oxidizing bacteria from marine sediments and hydrothermal vents. Appl Environ Microbiol 66, 3125-3133.

Thompson, J. D., Gibson, T. J., Plewniak, F., Jeanmougin, F. \& Higgins, D. G. (1997). The CLUSTAL_X windows interface: flexible strategies for multiple sequence alignment aided by quality analysis tools. Nucleic Acids Res 25, 4876-4882.

Vetriani, C., Speck, M. D., Ellor, S. V., Lutz, R. A. \& Starovoytov, V. (2004). Thermovibrio ammonificans sp. nov., a thermophilic, chemolithotrophic, nitrate-ammonifying bacterium from deep-sea hydrothermal vents. Int J Syst Evol Microbiol 54, 175-181.

Vetriani, C., Chew, Y. S., Miller, S. M., Yagi, J., Coombs, J., Lutz, R. A. \& Barkay, T. (2005). Mercury adaptation among bacteria from a deepsea hydrothermal vent. Appl Environ Microbiol 71, 220-226.

Voordeckers, J. W., Starovoytov, V. \& Vetriani, C. (2005). Caminibacter mediatlanticus sp. nov., a thermophilic, chemolithoautotrophic, nitrate-ammonifying bacterium isolated from a deep-sea hydrothermal vent on the Mid-Atlantic Ridge. Int J Syst Evol Microbiol 55, 773-779.

Xu, H. H. \& Tabita, F. R. (1996). Ribulose-1,5-bisphosphate carboxylase/oxygenase gene expression and diversity of Lake Erie planktonic microorganisms. Appl Environ Microbiol 62, 19131921. 